\title{
USE OF ARTIFICIAL NESTS FOR REARING AND STUDYING POLISTES WASPS*
}

\author{
By Stefano Turillazzi \\ Istituto di Zoologia, Università di Firenze, \\ Italy
}

\section{INTRODUCTION}

Artificial honeycombs are habitually used in bee-keeping (Chauvin, 1968) but, to the best of my knowledge, such nests have never been used with social wasps. Recently the adoption of artificial nests was obtained in Polistes (Turillazzi et al., 1979) and the initial results of this study suggest that the technique could be of use in solving some problems regarding the social life of wasps. This paper describes the various kinds of nests used in rearing and studying Polistes.

\section{Materials And Methods}

Specimens of Polistes gallicus (L.) and a few P. omissus (Weyrauch) were offered nests made of either plexiglas, glass, aluminium foil, plastic straws $(\phi 5 \mathrm{~mm}$, length $15 \mathrm{~mm})$ or gelatin capsules $(\phi 5.2$ and $6 \mathrm{~mm}$, length 13.4 and $15.2 \mathrm{~mm}$, volume 0.3 and $0.4 \mathrm{~cm}^{3}$ ). Paper materials, which the wasps could have easily destroyed or modified, were avoided.

Adults were confined in a limited space with an artificial nest, in which larvae from a normal nest had already been transplanted, and this forced contact usually persuaded the wasps to adopt the nest. After a few hours the nest was transferred to a plexiglass cage $(15 \mathrm{~cm}$ $X$ side) and affixed with the axes of the cells approximately horizontal in order to prevent the larvae from falling out. Transplanted pupae were kept in place and also protected from being killed by the nurses, by a tissue-paper cover over the opening of the cell. The paper was then broken by wasps at emergence.

Adoption was also obtained by substituting for a normal nest made directly in a plexiglas cage with an artificial one containing offspring from the former nest. In one instance, a foundress was removed from

*Manuscript received by the editor October 10, 1980. 
her newly-founded nest ( 4 cells) and confined in a small container with a few artificial cells (gelatin capsules) and no construction material. She laid her eggs directly in the artificial cells and continued to rear the larvae, the only time artificial cells were utilized without resorting to offspring transplant.

\section{RESUlts AND Discussion}

The adults solicit trophallactic exchanges just as soon as they find larvae within the artificial cells. The larvae were often pulled out of the cells and killed, usually because they had been damaged during transferring. A nest can be considered as adopted when all cannibalism has ceased, and at least one of the adults has begun to nourish the larvae normally with food placed in the cage. Some adults refused to return to the nest.

A) Nests closely resembling natural nests

A total of 21 nests, each formed of seven gelatin capsules, plus one of seven glass test-tubes (length $3 \mathrm{~cm}$, filled with cotton to decrease their volume) (Fig. 1, 2) were affixed to the cages by wooden peduncles. Of 22 nests, 16 ( $73 \%$ including the glass "nest") were adopted. The transparent walls allowed satisfactory observation of the adult-larva relationships and larval growth.

The adults that adopted artificial nests did not substantially modify their behavior.

The dominant female laid eggs without any difficulty in the artificial cells, placing as many as three in the larger capsules. Once the nest had been adopted, the cells were constantly licked, probably due to the lack of mouthing substance on the walls of the artificial cells.

When furnished with paper, the wasps enlarged the artificial cells and contructed new ones, beginning in the dihedral angles formed by the walls of adjacent capsules. Additional cells were then constructed in contact with the natural rather than the artificial cells, with the result that the nest expanded in one direction - usually downwardin nests with horizontal cells (Fig. 1B). Cells with their axes oblique to those of the artificial cells, and not begun in the dihedral angles, were constructed without any peduncle near the mouth of one of the glass test-tubes (Fig. 2). The wasps continued to reinforce the artificial peduncle even though this was abnormally distant from the newly constructed cells. 

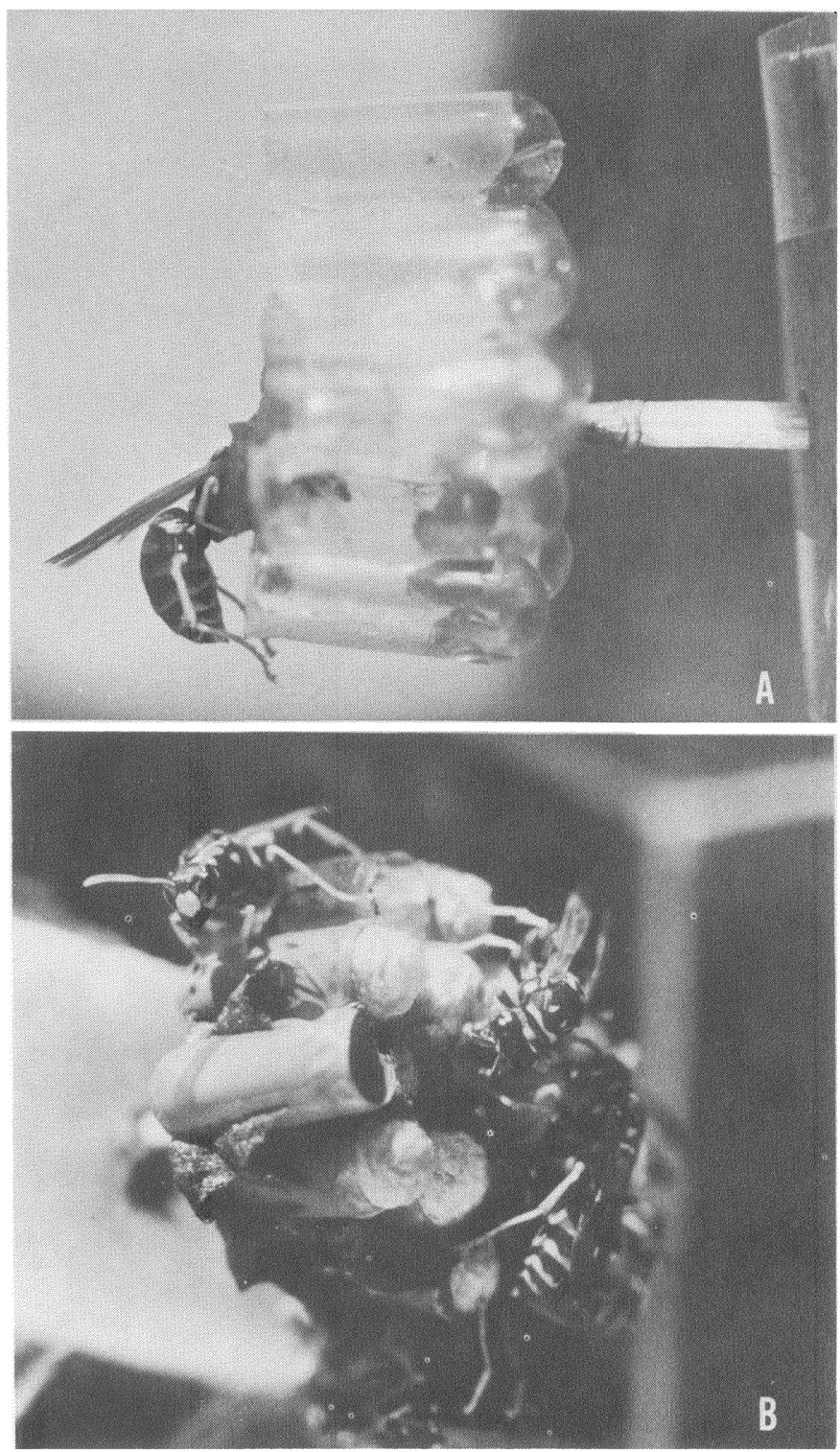

Fig.1. Gelatin capsule nests. 


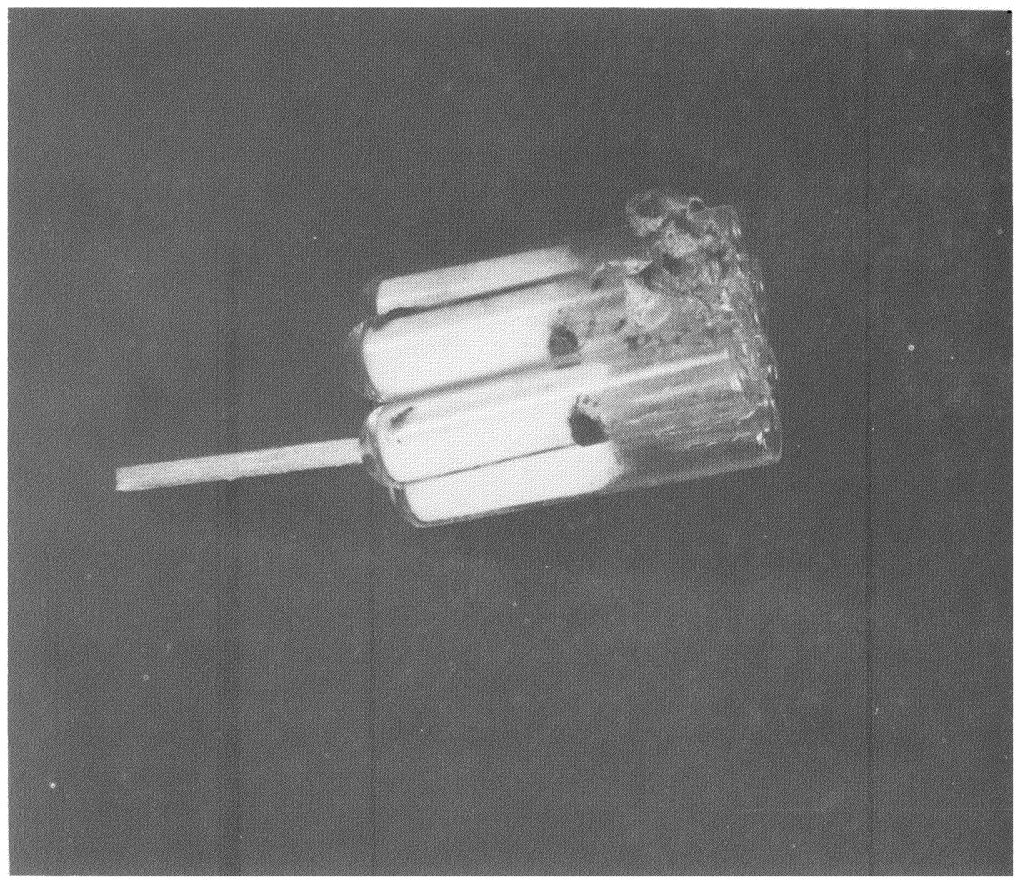

Fig. 2. Glass test-tube nest.

\section{B) "Sandwich" nests}

Two nests, which I dubbed "sandwich", consisted of two parallel glass slides $5 \mathrm{~mm}$ apart divided into cells by plastic partitions $5 \mathrm{~mm}$ apart (Fig. 3). The square entrance of the cells had no apparent effect on larval and adult behavior in the one nest adopted, and facilitated observation. These nests were affixed directly to the cage wall, without any peduncle or space behind the comb. On these, the nurses preferred the zone midway between the slides in direct contact with alveolar openings, while the less active females preferred the area between the top of the nest and roof of the cage.

\section{C) Re-use of artificial nests}

One sandwich and two capsule nests were re-used and enlarged the second year by foundresses born on the respective nests the preceding season. The sandwich nest, which had not been enlarged at all the preceding year, was noticeably expanded (Fig. 3B) after the artificial cells had been re-used to rear the first larvae. 


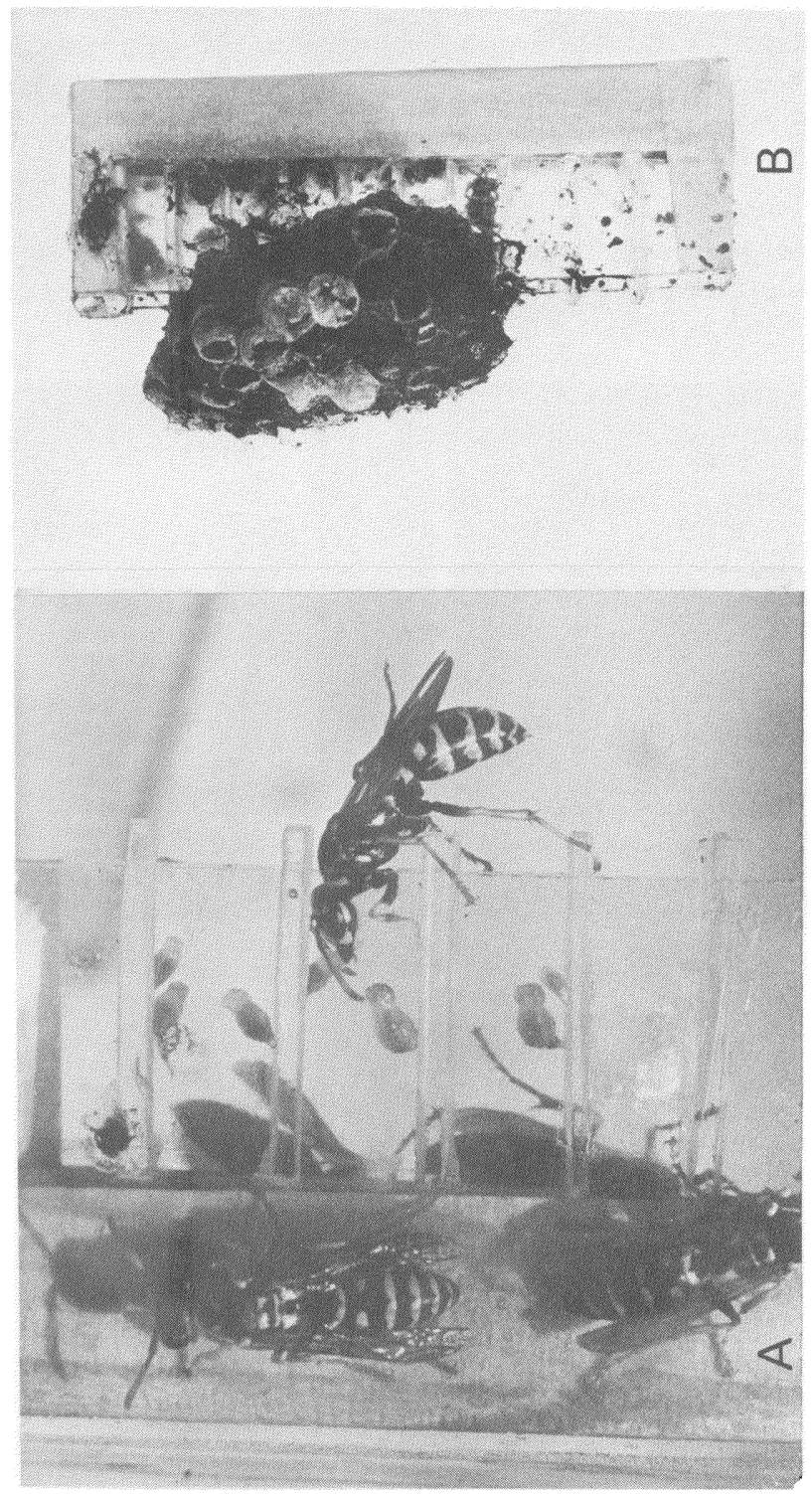


D) Flat nests with removable, interchangeable cells

Two types were tested: one formed of transparent and opaque gelatin capsules inserted into holes drilled in the cage wall (Fig. 4), and one consisting of 80-82 plastic straws cells gathered in a plastic container which fit into a hole $(\phi 58 \mathrm{~mm})$ in the cage wall (Fig. 5). Flat nests allow for the observation of individual larvae as each cell can be removed and controlled. Construction was prohibited in order to maintain the form and visibility of the artificial nests. The results obtained on these nests are shown in Table I. Nine out of 12 nests of
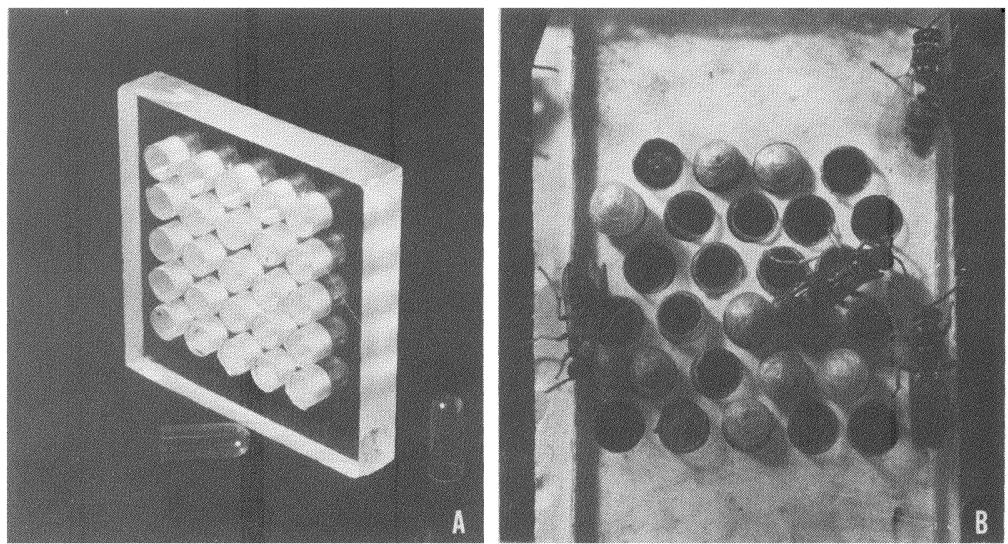

Fig. 4. Flat gelatin-capsule nest before and during use.

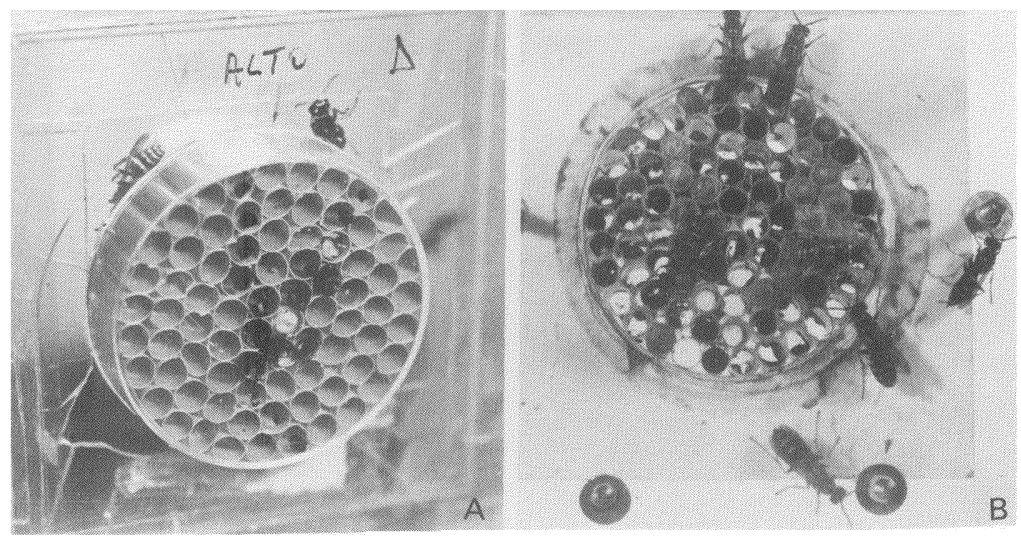

Fig. 5. Flat plastic-straw nest viewed from outside and inside the cage. 
Table I. Flat nests (first and second type) with removable cells. Shown are the number and type of immature offspring transplanted, number of adults on the nest, nest acceptance (+ adoption, \pm partial adoption, - refusal) egg-laying, larvaphagy, destruction of pupae by the adults, number of wasps emerged from larvae raised at least partially in artificial cells, and differences between wasps emerged and immature offspring transplanted.

\begin{tabular}{|c|c|c|c|c|c|c|c|c|c|c|}
\hline 芯 & $\begin{array}{l}: 0 \\
.0 \\
0 \\
0\end{array}$ & 疍 & 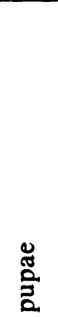 & 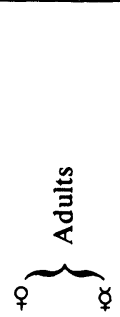 & 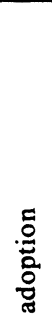 & 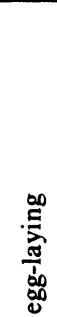 & 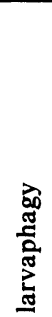 & 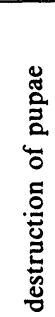 & & 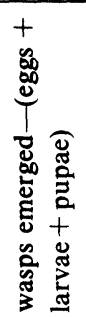 \\
\hline
\end{tabular}

$\begin{array}{rrrrrrrrrrrr}\text { A } & 0 & 0 & 0 & 1 & 0 & + & + & + & - & 0 & 0 \\ \text { B } & 3 & 11 & 0 & 2 & 0 & \pm & - & + & - & 0 & -14 \\ \text { C } & 2 & 5 & 0 & 1 & 3 & + & - & + & - & 1 & -6 \\ \text { D } & 0 & 7 & 0 & 1 & 3 & + & + & + & - & 26 & +19 \\ \text { E } & 3 & 8 & 0 & 1 & 6 & + & - & - & + & 2 & -9 \\ \text { F } & 0 & 7 & 0 & 1 & 7 & + & + & - & - & 10 & +3 \\ \text { G } & 2 & 7 & 0 & 0 & 3 & + & + & - & - & 2 & -7 \\ \text { H } & 3 & 6 & 2 & 0 & 4 & + & - & + & - & 4 & -5 \\ \text { I } & 16 & 5 & 2 & 0 & 0 & \pm & - & + & - & 3 & -20 \\ \text { J } & 0 & 19 & 5 & 0 & 0 & + & + & + & + & 4 & -20 \\ \text { K } & 0 & 0 & 11 & 0 & 0 & - & - & - & - & 0 & -11 \\ \text { L } & 0 & 0 & 19 & 0 & 0 & + & + & - & + & 12 & -7\end{array}$

\begin{tabular}{|c|c|c|c|c|c|c|c|c|c|c|c|}
\hline A & 1 & 2 & 0 & 4 & 0 & + & + & - & - & 24 & +21 \\
\hline B & 8 & 6 & 0 & 3 & 0 & + & + & + & - & 20 & +6 \\
\hline C & 0 & 10 & 0 & 6 & 0 & + & + & + & - & 3 & -7 \\
\hline D & 2 & 4 & 1 & 4 & 0 & + & + & + & - & 21 & +14 \\
\hline $\mathrm{E}$ & 0 & 6 & 12 & 5 & 0 & + & + & + & - & 55 & +37 \\
\hline $\mathrm{F}$ & 3 & 4 & 0 & 5 & 0 & + & + & + & - & 2 & -5 \\
\hline G & 3 & 5 & 0 & 2 & 0 & - & - & - & - & 0 & -8 \\
\hline $\mathbf{H}$ & 2 & 6 & 0 & 4 & 0 & - & - & - & - & 0 & -8 \\
\hline I & 7 & 6 & 0 & 2 & 0 & - & - & + & - & 0 & -13 \\
\hline $\mathbf{J}$ & 4 & 10 & 0 & \multicolumn{2}{|c|}{4} & - & - & + & - & 0 & -14 \\
\hline $\mathbf{K}$ & 4 & 11 & 0 & \multicolumn{2}{|c|}{4} & - & - & + & - & 0 & -15 \\
\hline $\mathbf{L}$ & 3 & 9 & 0 & 1 & 14 & + & + & + & - & 59 & +47 \\
\hline $\mathbf{M}$ & 5 & 6 & 2 & \multicolumn{2}{|c|}{5} & + & + & + & - & 0 & -13 \\
\hline $\mathbf{N}$ & 0 & 12 & 0 & \multicolumn{2}{|c|}{3} & - & - & + & - & 0 & -12 \\
\hline O & 0 & 51 & 0 & \multicolumn{2}{|c|}{22} & + & + & + & + & 27 & -24 \\
\hline $\mathbf{P}$ & 0 & 7 & 1 & & 6 & + & + & - & - & 12 & +4 \\
\hline
\end{tabular}


the first type and ten out of 16 of the second type were adopted. Differences between the number of emerged individuals and transplanted immature offspring were positive in two out of 12 nests of the first type and six out of 16 nests of the second type. However, the production of the artificial colonies - although lower-was occasionally comparable to that of natural ones [see Pardi (1951, p. 381) on 6 natural nests of $P$. gallicus].

The growth curve of three larvae in a gelatin capsule nest attended by six wasps and kept at about $25^{\circ} \mathrm{C}$, is shown in Fig. 6. Larval weight, registered daily by weighing the entire cell, varied initially due to the different quantity of honey accumulated in the cells, then followed almost identical curves during the period of greatest growth between the 11th and 19th day. A rapid decline in weight occurred immediately after pupation due in part to the emission of meconium and, perhaps, to water loss.

\section{E) Orientation of pupating larvae in transparent cells}

In natural nests each pupating larva first spins a silk dome over the open end of its cell, then turns back and spins the posterior end of the cocoon, returning finally to its original position. Some of the larvae raised in transparent cells failed to turn after spinning the posterior end of their cocoons and pupated without reorienting to the front of the cells. The effect of light on this orientation was tested by rearing larvae in three types of cell: transparent capsules illuminated from the side, capsules with opaque walls and transparent bottoms illuminated from behind, and completely opaque capsules illuminated from the front. The results obtained with these nests, shown in Table II suggest the presence of a phototactic component in the orientation of the larva during pupal formation. Further tests are in progress to test for the presence of other components as well.

\section{F) Malformation of specimens emerged from artificial nests}

The shape and position of the wings in some newly emerged imagoes raised in gelatine capsules were so malformed as to prohibit flight. When raised in shorter-than-normal cells, the body was compressed cephalo-caudally (Fig. 7). Specimens reared in plastic straws cells seldom presented such anomalies. 


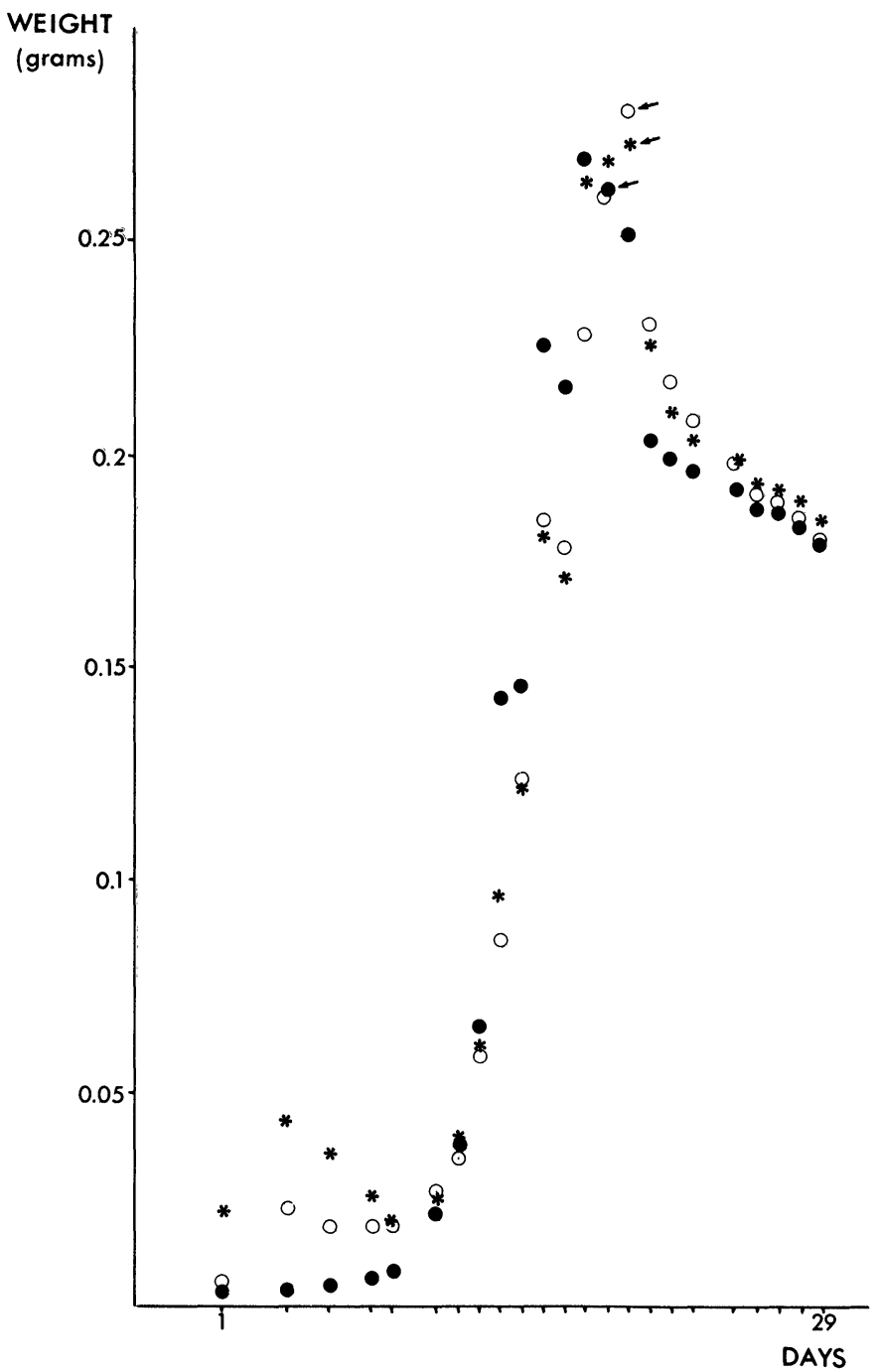

Fig. 6. Larval growth curve (egg to emergence) obtained by daily weighing of three larvae in their artificial cells on a flat nest. Each symbol represents the weight of a single individual without the cell. Arrows indicate the day of pupation. 
Table II. Pupal position in artificial cells. The data were analyzed with the $\chi^{2}$ test of the null hypothesis that $100 \%$ of the larvae will pupate normally and $0 \%$ in the reversed position.

\begin{tabular}{cccccl}
\multicolumn{1}{c}{ cells } & $\begin{array}{r}\text { direction of } \\
\text { illumination }\end{array}$ & normal & reversed & \\
Walls + bottom opaque & front & 19 & 2 & N.S. \\
Walls opaque, bottom transparent & bottom & 1 & 9 & $\mathrm{P}<0.001$ \\
Walls + bottom transparent & side & 7 & 8 & $\mathrm{P}<0.001$
\end{tabular}
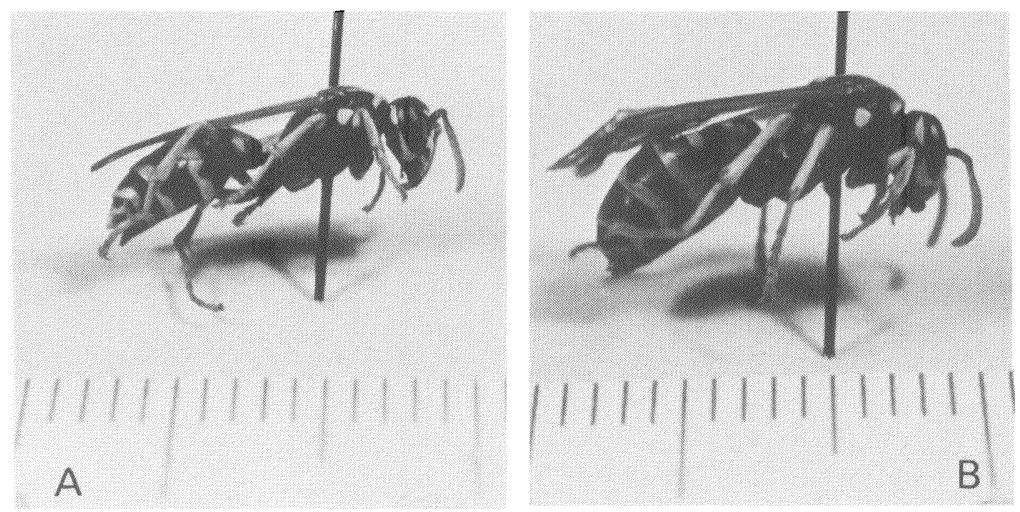

Fig. 7. Females born from a normal (A) and gelatin-capsule nest (B).

\section{ACKNOWLEDGEMENTS}

I wish to thank Prof. L.Pardi for reviewing the manuscript and Mrs. S.Ferrati Berti for her help in the research.

\section{Literature Cited}

Chauvin, R. (sous la direction de)

1968. Traitè de biologie de l'abeille. 5 vols. Masson, Paris.

PARDi, L.

1951. Ricerche sui Polistini. 12. Studio della attività e della divisione di lavoro in una società di Polistes gallicus (L.) dopo la comparsa delle operaie. Arch.zool.ital. 36: 263-431.

Turillazzi, S., S. Tonarelli and A. Ugolini

1979. Adoption of artificial nests in Polistes (Hymenoptera Vespidae). Monitore zool.ital.(N.S.) 13: 218. 

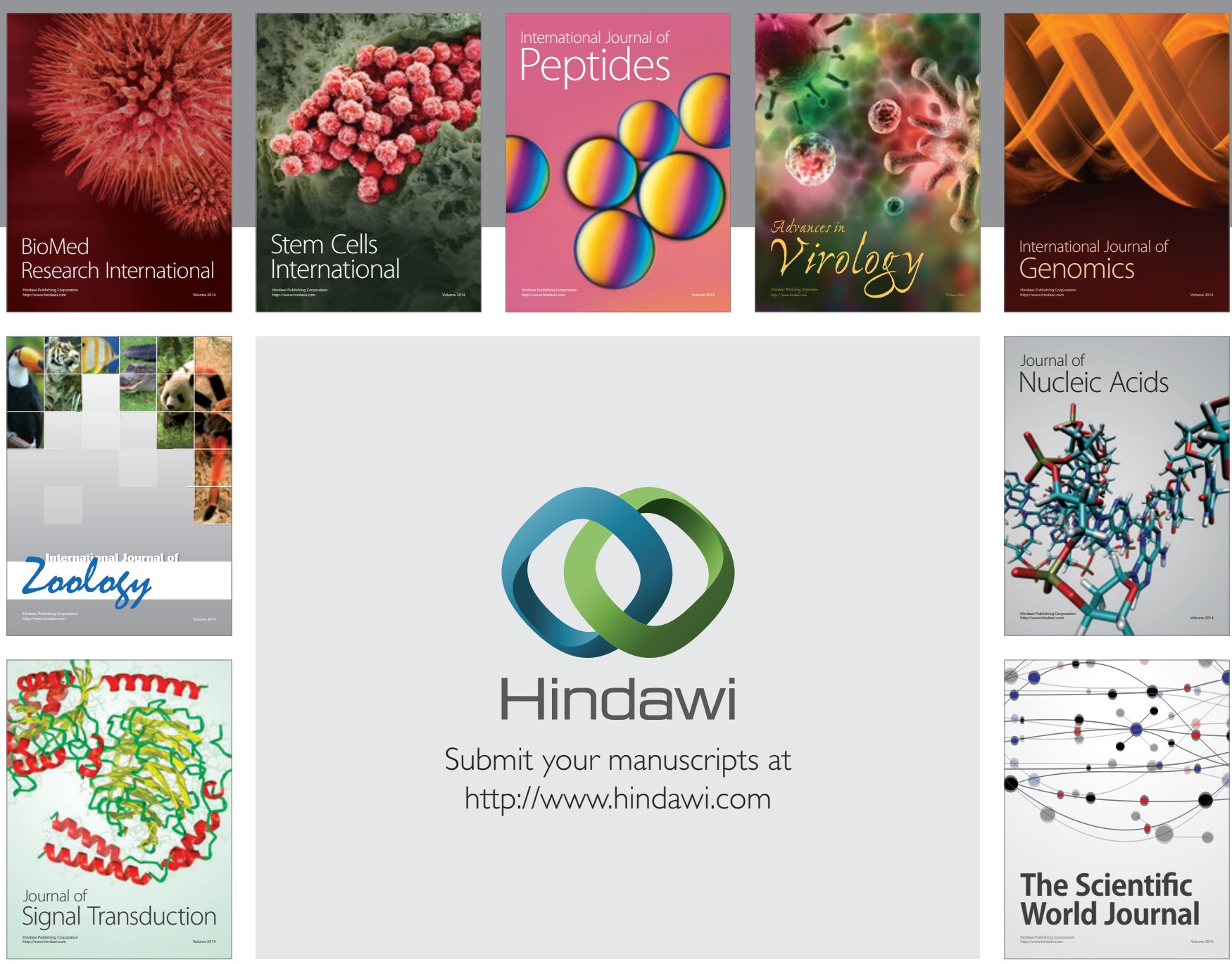

Submit your manuscripts at

http://www.hindawi.com
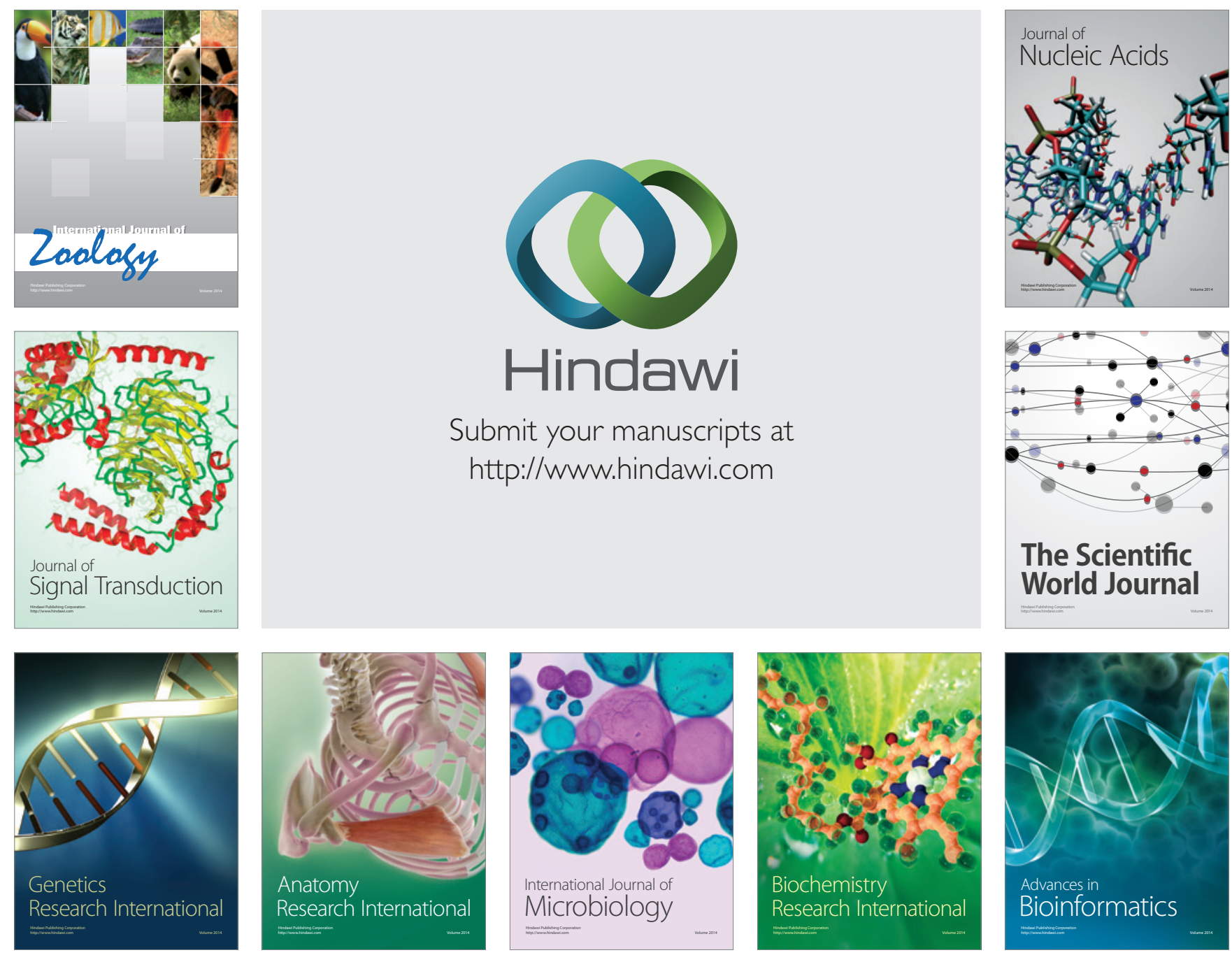

The Scientific World Journal
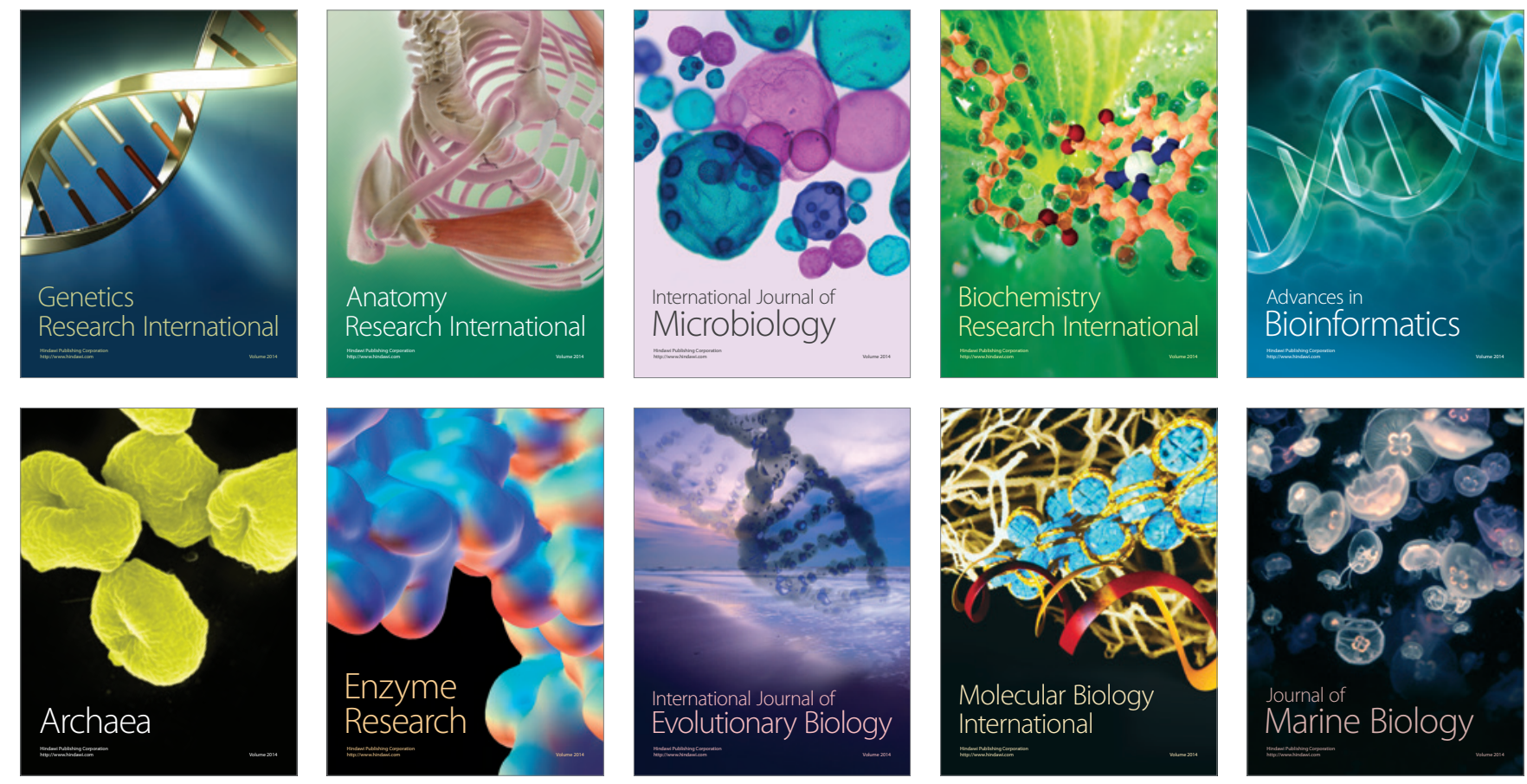